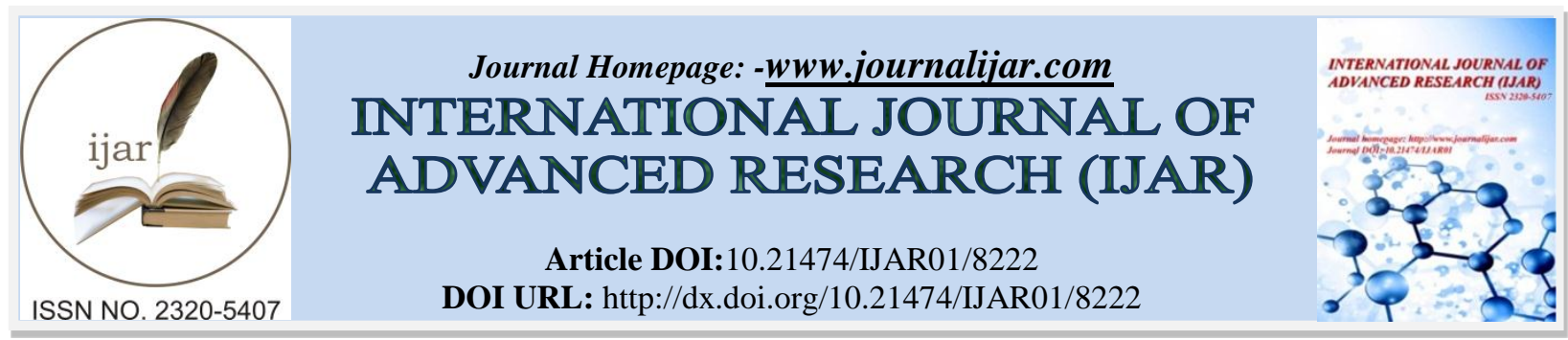

RESEARCH ARTICLE

\title{
POTENTIAL APPLICATION OF MICROENCAPSULATION IN THE FOOD INDUSTRY.
}

\section{Dayane de Melo Barros ${ }^{1}$, Erilane de Castro Lima Machado ${ }^{2}$, Danielle Feijó de Moura ${ }^{1}$, Maria Heloisa Moura de Oliveira $^{3}$, Tamiris Alves Rocha ${ }^{4}$, Silvio Assis de Oliveira Ferreira ${ }^{4}$, Roberta de Albuquerque Bento da Fonte $^{2}$ and Ranilson de Souza Bezerra ${ }^{5}$.}

1. Mestre em Saúde Humana e Meio Ambiente - Centro Acadêmico de Vitória, Universidade Federal de Pernambuco, CAV/UFPE - Pernambuco.

2. Doutora em Nutrição - Universidade Federal de Pernambuco - Pernambuco.

3. Discente de bacharelado em Nutrição - Centro Acadêmico de Vitória, Universidade Federal de Pernambuco, CAV/UFPE- Pernambuco.

4. Mestre em Bioquímica e Fisiologia - Universidade Federal de Pernambuco - Pernambuco.

5. Doutor em Ciências Biológicas - Universidade Federal de Pernambuco - Pernambuco.

\section{Manuscript Info}

Manuscript History

Received: 16 October 2018

Final Accepted: 18 November 2018

Published: December 2018

Key words:

microparticle, production, review, techniques, food technology.

\section{Abstract}

In the food sector, encapsulation is a process of coating one or more food ingredients through an edible capsule. This is a relatively new technology that has been used successfully in the food industry. Several techniques have been used in the production of microparticles, such as: extrusion, spray drying, complex coacervation, fluidized bed, lyophilization, internal and external ionic gelation, liposomes and molecular inclusion. Microencapsulation, in addition to increasing the performance and availability of active agents, has solved limitations in the use of food ingredients, since it can suppress or attenuate undesirable organoleptic characteristics (flavors, odors and color) of some compounds, reduce volatility and reactivity and increase their stability under adverse environmental conditions (oxygen, light, moisture, $\mathrm{pH}$ and incompatible agents).The present study presents a review of the literature on encapsulation in food technology - history of encapsulation/microencapsulation, encapsulating agent, encapsulated agent, controlled release mechanisms, techniques used in microencapsulation and potential application in the food industry.

Copy Right, IJAR, 2017,. All rights reserved.

\section{Introduction:-}

The food industry has been using formulations in the micrometric range to increase the shelf life of perishable foods, as well as incorporating vitamins and nutraceutical compounds, with the interest of offering a product differentiated in the market and that provides actions beneficial to human health (HERRERO et al., 2006, COMAN et al., 2012; SILVA et al., 2014; SILVA et al., 2015).

In this scenario microencapsulation has applicability in several areas, such as pharmaceutical, cosmetic and agrochemical, being also used in the alimentary area (REBELLO, 2009; PHISUT, 2012; NESTERENKO et al., 2013).

Corresponding Author:-Dayane de Melo Barros.

Address:-Mestre em Saúde Humana e Meio Ambiente - Centro Acadêmico de Vitória, Universidade 
In the segment of technology associated with the encapsulation of food products, in an environment of competitiveness, the innovation factor is paramount. The technological innovation in the systems of encapsulation of ingredients allows creating differentials in products that can provide the most varied sensations for the consumer. The encapsulation technology is in increasing expansion and constant evolution, being of competence of the scientific community of the science and technology of food and of the industries to be kept abreast both in relation to the use of new materials, as in the techniques employed, that transform ideas products with high added value (azeredo, 2005; favaro-trindade, pinho and rocha, 2008; nedovic et al., 2011; oliveira junior et al., 2012; pereira et al., 2018).

In the food industry, encapsulation has been used as a way to enable liquid and solid ingredients to effectively barrier against environmental and/or chemical interactions, until the desired release (CARMO et al., 2015).One of the major advantages of microencapsulation technology is the controlled release, whose technique allows extending the spectrum of applications of the compounds of interest, being considered not only an additional, but also a source of new ingredients with unique characteristics (GOUIN, 2004).

The present study aimed to identify available evidence on the potential application of microencapsulation in the food industry. The present study aimed to identify available evidence on the potential application of microencapsulation in the food industry.

\section{History about encapsulation/microencapsulation:}

the encapsulation consists of a technology of packaging of particles (liquid, gaseous or solid) in edible capsules being considered a favorable tool to optimize the release of molecules and living cells through particles (kailasapathy and masondole, 2005; nedovic et al., 2011).the carrier material forming the capsule is known as encapsulant, wall material or cover and the encapsulated material may be called encapsulated agent, active agent, core or fill (azeredo, 2005; suave et al., 2006).

The first studies of the use of the microencapsulation technique were verified in the 30's mediated by the US National Cash Register, which became a pioneer in the commercialization of carbonless copy paper (in the 1950s). This paper was covered by a thin layer of colorless ink microcapsules. This paper was covered by a thin layer of colorless ink microcapsules. When writing with a pen, that is, by pressing under the surface of the paper, there was the rupture of the microcapsules leading to the release of the colorless ink that, when interacting with the reagent, became colored, generating on the sheet underneath a copy of what was being written in the first role (FIB, 2017).

The distinction between encapsulation, microencapsulation and nanoencapsulation is basically the size of the capsule.According to Rebello (2009) the capsules can be classified according to the diameter into three categories: macrocapsules $(>5000 \mu \mathrm{m})$, microcapsules $(0.2-5000 \mu \mathrm{m})$ and nanocapsules $(<0.2 \mu \mathrm{m})$.

The microparticles are subdivided into microspheres and microcapsules (Figure 1), according to their structure, so that capsules where the nucleus is evenly dispersed in a matrix result in so-called microspheres and capsules in which the nucleus concentrates in the central region, wrapped by a defined and continuous film of the wall material characterize the microcapsules. The most relevant difference between the microspheres and the microcapsules is that in the microspheres a small fraction of the "encapsulated" material remains exposed on the surface, which is prevented by the true encapsulation (AZEREDO, 2005; SUAVE et al., 2006).

Figure 1:-Microsphere (A): the nucleus is distributed in a polymer matrix; Microcapsule (B) the core is surrounded by the encapsulating agent (polymer)

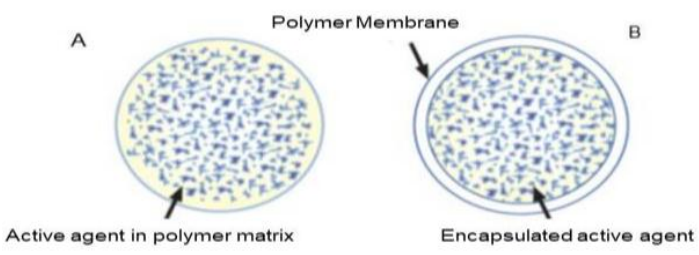

Source: Adapted from Suave et al., 2006. 


\section{Encapsulating agent or wall material:}

In the microencapsulation system a wide quantitative of encapsulating agents or wall materials has been employed, which are responsible for the coating of the active agents (encapsulated), leading to the formation of the microparticles (AZEREDO, 2005).

Various materials can be used as encapsulating agents to obtain good coverage, these agents may be of natural, semi-synthetic and synthetic origin as shown in Table 1.

Table 1:-Encapsulating agents used in encapsulation according to their origin

\begin{tabular}{|l|c|}
\hline \multicolumn{1}{|c|}{ Encapsulating agents } & Examples \\
\hline Natural & $\begin{array}{c}\text { Sodium alginate, carrageenan, gelatin, gum arabic, agar, } \\
\text { dextran, chitosan, caseinate, sucrose and wax. }\end{array}$ \\
\hline Semisynthetic & $\begin{array}{c}\text { Hydroxypropylcellulose, methylcellulose, sodium } \\
\text { carboxymethylcellulose, myristyl alcohol, monoglycerol, } \\
\text { diacylglycerol or dipalmitate, monostearate, glycerol distearate } \\
\text { and tristearate, cellulose acetate, cellulose nitrate, } \\
\text { ethylcellulose. }\end{array}$ \\
\hline Synthetic & Polymers of acrylic acid and copolymers. \\
\hline
\end{tabular}

Source: Adapted from ANSON, 2005 and Laurenti and Garcia, 2013.

The choice of a specific encapsulating agent depends on several factors, among which are: non-reactivity with the material to be encapsulated, the method used to form the microcapsule, the ideal release mechanism, the physical and chemical properties of the nucleus and of the wall and economic factors (AZEREDO, 2005; FAVAROTRINDADE, PINHO and ROCHA, 2008).

According to Weiss, Takhistov and Mcclements (2006) each type of encapsulant has specific advantages and disadvantages for the encapsulation, protection, release of functional ingredients, as well as cost, ease of use, biodegradability and biocompatibility.

The efficiency of the microparticles depends on their surface structure, since, while the outer film forms microparticles free of deformation, the functionality of the wall material in the retention of the active agent will be greater, i.e., the active agent will be surrounded and protected from the through the encapsulating agent (ROSENBERG and YOUNG, 1993).

The encapsulating agents commonly used to encapsulate food ingredients are: polymers, polysaccharides, cellulose and derivatives, lipids, proteins and certain inorganic compounds. Among polymers of natural origin, polysaccharides from the marine ecosystem such as sodium alginate, carrageenan and chitosan have their increasing application in encapsulation systems, these compounds can generate a more appropriate environment in specific regions of the food, for example, a more acidic environment on the surface of the product, favoring the effect of organic acids used as preservatives (MAIA, 2013).Torres and Karel (1985) achieved a concentration of sorbic acid on the surface of intermediate moisture products. The low surface $\mathrm{pH}$ required for the preservative efficiency was maintained by carrageenan.

\section{Encapsulated agent or core:}

According to Brasileiro (2011), the microparticles have a nucleus, in which the bioactive agents are found, this internal nucleus can be present in any physical state (liquid, solid and gaseous).

The core may be formed by a mixture of various agents such as: stabilizers, diluents and release modulating agents (VENKATESAN, MANAVALAN and VALLIAPPAN, 2009).The amount of materials that can be encapsulated is variable, among these compounds include hydrophobic and hydrophilic substances (JAIN, 2004).

Among the materials that can be encapsulated for use in the food industry are oils, vitamins, protein hydrolysates, acids, amino acids, flavorings, sweeteners, minerals, dyes, enzymes and microorganisms (JACKSON and LEE 1991; AUGUSTIN et al., 2001; FÁVARO-TRINDADE, PINHO and ROCHA, 2008). 


\section{Mechanism of controlled release of encapsulated agent or core:}

The encapsulation enables the core to be isolated from the external environment under a controlled release mechanism, that is, up to the moment at which it is intended to be released.In order to improve the efficiency of the microencapsulation system, it is necessary to determine the effect of the microencapsulation in the microencapsulation system (GOUIN, 2004; SILVA et al., 2014).The main mechanisms involved in the release of the active agent are: diffusion, solvent activation, degradation activation, activation by $\mathrm{pH}$ control, activation by temperature and activation by pressure.

\section{Diffusion-controlled release:}

In the food industry, the diffusion mechanism has been widely used, being represented as one of the most relevant. The diffusion is based on the displacement of the active agent through the matrix, moving from a more concentrated region to a less concentrated region (AZEREDO, 2005; SILVA et al., 2014; RODRÍGUEZ et al., 2016).

It occurs particularly when the microparticle is intact (SILVA et al., 2014), being controlled by limitations of the mass transfer in the layer between the polymer matrix and the medium (PEREIRA et al., 2018).

According to the application of the microparticles it may be desirable for the diffusion of the active agent by means of the encapsulating agent to take place more slowly, that is, it does not immediately solubilize. In view of this, the transport of the active agent in the diffusion will depend on its ability to cross the membrane of the wall material which is porous, or rather its solubility in the matrix system (matalanis et al., 2011; zandi et al., 2015 rodríguez et al., 2016).the diffusion also depends on the size, shape, physical state and arrangement of the wall material (sobrinho and farias, 2012).

\section{Solvent Activated Release:}

In activation by contact with a solvent, the matrix can be released by complete dissolution of the wall material, rapidly releasing the food matrix or through its expansion, favoring the release.In this mechanism, cleavage of the intermolecular bonds present in the polymer chains takes place, during which degradation occurs the release of the encapsulated agent.The temperature is a factor that can influence in this process, through the expansion or contraction of the nucleus, dispersing the active agent (frascareli et al., 2012).

\section{Degradation-enabled release:}

Degradation-activated release occurs through the degradation of proteins and lipids, by the activity of protease and lipase enzymes, respectively (ROSEN, 2006).

\section{pH controlled activated release:}

Changes in $\mathrm{pH}$ may result in changes in the solubility of the wall material of the microparticles, providing release of the active agent. As for example, probiotic microorganisms can be encapsulated to tolerate acidic $\mathrm{pH}$, and only be activated and dispersed at the alkaline intestinal pH (TOLDRÁ and REIG, 2011).

\section{Temperature Activated Release:}

Changes in temperature can also be a form of release of the encapsulated active agent. This process can occur through temperature sensitive release, used for compounds that collapse or expand when a critical temperature is reached and melt activated release, which is related to the melting of wall material (such as a modified wax or lipid) due to temperature elevation (DEPYPERE et al., 2003, PARK and MAGA, 2006).

\section{Pressure activated release:}

Another factor promoting the release of the active agent is through the pressure applied on the wall material of the microparticle, for example, the release of flavor compounds into chewing gums during chewing (DEPYPERE, et al., 2003; WONG et al. 2009).

\section{Techniques employed in microencapsulation:}

There are several techniques that are used or at least studied about microencapsulation, these can be classified in: physicochemical, physical or chemical methods (Table 2) for different food ingredients (FÁVARO-TRINDADE, PINHO and ROCHA, 2008; SOHAIL et al., 2011 and MARSANASCO, 2011). 
Table 2:-Classification of encapsulation techniques

\begin{tabular}{|l|l|}
\hline \multicolumn{1}{|c|}{ Methods } & \multicolumn{1}{|c|}{ Techniques } \\
\hline Physico-chemical methods & $\begin{array}{l}\text { Simple or complex coacervation, liposomes, micelles, emulsions, } \\
\text { internal ionic gelation, solvent evaporation, process with } \\
\text { nanostructured lipid matrices; }\end{array}$ \\
\hline Physicalmethods & $\begin{array}{l}\text { External ionic gelation, extrusion, spray drying, pan coating, freeze- } \\
\text { drying, fluidized bed, supercritical fluids and spray coating; }\end{array}$ \\
\hline Chemical methods & Molecular inclusion and polymerization. \\
\hline
\end{tabular}

Although there are several techniques of microencapsulation, the biggest challenge is to choose the most efficient and appropriate method, taking into account the application to be used and the type of coating material (ANAL and SINGH, 2007).

Description of the main techniques and potential application in the food industry:

The main techniques used in microencapsulation of active agents in food (Table 3) include: extrusion, spray drying, complex coacervation, fluidized bed, lyophilization, internal and external ionic gelation, liposomes and molecular inclusion (AZEREDO, 2005; BRASILEIRO, 2011).

Table 3:-Application of microencapsulation methods in the food industry

\begin{tabular}{|c|c|c|}
\hline Technique & Food Compounds & Reference \\
\hline Extrusion & $\begin{array}{c}\text { Essential oils of orange (D- } \\
\text { limonene), canola essential oil, kenaf } \\
\text { seed oil. }\end{array}$ & $\begin{array}{l}\text { Wang, Waterhouse and Sun- } \\
\text { Waterhouse(2013), } \\
\text { Lévic et al. (2015), } \\
\text { Chew et al. (2015). }\end{array}$ \\
\hline Spray Drying & $\begin{array}{c}\text { Essential oils of orange (D- } \\
\text { limonene), essential oil of } \\
\text { cinnamaldehyde, clove essential oil } \\
\text { (eugenol), oregano essential oil, basil } \\
\text { oil essential oil, Eucalyptus } \\
\text { staigeriana essential oil, rosemary } \\
\text { essential oil, coffee oil, linseed oil. }\end{array}$ & $\begin{array}{c}\text { Pereira (2007), } \\
\text { Carvalho (2009), } \\
\text { Frascareli (2010), } \\
\text { Carmona (2011), } \\
\text { Müller (2011), } \\
\text { Carneiro (2011), } \\
\text { Fernandes (2013), } \\
\text { Garcia (2013), } \\
\text { Felix (2014), } \\
\text { Herculano (2014), } \\
\text { Felix (2014). }\end{array}$ \\
\hline Complex coacervation & $\begin{array}{l}\text { Poppy seed oils, fish oils, thyme } \\
\text { essential oil, orange essential oil (D- } \\
\text { limonene), buriti oil. }\end{array}$ & $\begin{array}{l}\text { Alvim and Grosso (2010), } \\
\text { Müller (2011), } \\
\text { Yang et al. (2015), } \\
\text { Gonçalves (2016), } \\
\text { Lemos (2017). }\end{array}$ \\
\hline Fluidized bed & $\begin{array}{l}\text { Particles of crystal sugar seeds, sugar } \\
\text { pellets, microcrystalline cellulose, } \\
\text { microcrystalline cellulose pellets, rice } \\
\text { and cassava flour, carnauba wax and } \\
\text { fish oil. }\end{array}$ & $\begin{array}{l}\text { Grosso and Vitali (2001), } \\
\text { Benelli et al. (2015), } \\
\text { Paulo (2017). }\end{array}$ \\
\hline Freeze-drying & $\begin{array}{l}\text { Carotenoids such as Lycopene, } \beta \text { - } \\
\text { carotenes, amino acids (valine), } \\
\text { Vitamins ( } \alpha \text {-Tocopherol). }\end{array}$ & $\begin{array}{c}\text { Desobry et al. (1997), } \\
\text { Farias et al. (2007). }\end{array}$ \\
\hline Ionic Gelation & $\begin{array}{l}\text { Polymers including proteins such as } \\
\text { collagen, albumin, gelatin, whey } \\
\text { proteins and caseinates; } \\
\text { polysaccharides such as alginate, } \\
\text { carrageenan, chitosan and pectin; } \\
\text { polyesters; acids ribonucleic (RNA) } \\
\text { and deoxyribonucleic (DNA), }\end{array}$ & $\begin{array}{l}\text { Anal and Singh (2007), } \\
\text { Zhang et al. (2007), } \\
\text { Barreto (2008), } \\
\text { Albini (2012), } \\
\text { Paglione (2018). }\end{array}$ \\
\hline
\end{tabular}




\begin{tabular}{|c|c|c|}
\hline & essential oils. & \\
\hline Liposomes & $\begin{array}{l}\text { Compounds such as ascorbic acid, } \\
\text { tocopherol, polyphenols, quercetin } \\
\text { and food products such as fish oil and } \\
\text { plant essential oils (terpinen-4-ol, } \\
\text { carvacrol and thymol). }\end{array}$ & $\begin{array}{c}\text { Liolios et al. (2009), } \\
\text { Frenzel and Steffen-Heins (2015), } \\
\text { Gibis et al. (2016), } \\
\text { Juveriya et al. (2016), } \\
\text { Amnuaikit (2016). }\end{array}$ \\
\hline Molecular Inclusion & $\begin{array}{l}\text { Linear or branched chain aliphatic } \\
\text { compounds, aldehydes, ketones, } \\
\text { alcohols, organic acids, fatty acids, } \\
\text { aromatic compounds and amines. }\end{array}$ & $\begin{array}{l}\text { Del Valle (2004), } \\
\text { Pandit et al. (2011), } \\
\text { Anconi et al. (2012), } \\
\text { Kuck (2016). }\end{array}$ \\
\hline
\end{tabular}

\section{Extrusion:}

Extrusion is a popular technique, because it is simple and low cost, moreover it does not involve the use of organic solvents and high temperatures, and consequently does not affect the material to be encapsulated (MORTAZAVIAN and SOHRABVANDI, 2006; PATIL et al., 2010; FAVARO-TRINDADE, HEINEMANN and PEDROSO, 2011; KENT and DOHERTY, 2014).

In the extrusion method, the molten or solution liquid core material is poured through the bore of a thin tube or syringe to form microdroplets, the size of which is dependent upon the orifice diameter and the material exit velocity.The drops contain the coating material or this is added when the drops fall or is injected. Solidification of the coating material may occur by solvent evaporation, solvent diffusion or chemical reaction (KRASAEKOOPT; BRANDARI and DEETH, 2003).

This method has been widely used for the microencapsulation of probiotics and volatile oils. It is emphasized that, one of the disadvantages of this technique is the formation of large particles, which limit the use of flavorings in applications where the taste is a determining factor (ETCHEPARE et al., 2016)

Chew et al. (2015) encapsulated kenaf seed oil by extrusion using pectin and alginate with chitosan coating, and evaluated changes in antioxidant and bioactive activities before and after in vitro digestion. The authors observed that microencapsulation of Kenaf seed oil offered a controlled and effective release system when compared to oil without encapsulation.

Wang, Waterhouse and Sun-Waterhouse (2013) investigated the feasibility of encapsulation of canola oil enriched with quercetin using alginate and pectin at different concentrations as coating materials. The addition of quercetin and the extrusion encapsulation increased the stability of the oil. Both formulations of alginate and pectin showed good results regarding the preservation of canola oil, evidencing it as a good option in the encapsulation of this type of substance.

In the study by Stojanovic et al. (2012), the extrusion technique was applied to encapsulate the aqueous extract of thyme in calcium alginate gel beads to produce dosage formulations containing polyphenolic compounds. The authors concluded that the use of the hydrogel material to encapsulate by extrusion of vegetable polyphenols improved its functionality and stability in food products.

When investigating extrusion encapsulation of a flavoring compound, D-limonene (compound present in citric essential oil).Lévic et al. (2015) have analyzed that the alginate particles with wall material of this compound are suitable for the incorporation of D-limonene maintaining its thermal stability under specific conditions.

\section{Spray Drying:}

Microencapsulation by spray drying involves the dispersion of the cells in a polymer solution, which is atomized in a drying chamber (SILVA et al., 2014).This leads to solvent evaporation and, consequently, the formation of the microcapsules (MARTÍN et al., 2015).

Spray drying includes: the preparation of the dispersion or emulsion to be processed, the homogenization of the dispersion and the atomization inside the drying chamber (GHARSALLOUI et al., 2007). During spray drying, the 
temperature of the droplets increases slightly, while its water content decreases, so, through the differences between the molecular weight of the water and the volatiles, the reduction in the diffusivity of the volatiles is greater than in the water, allowing, but good retention.

This common and low-cost technique is considered to produce microencapsulated food materials, equipment is readily available and production costs are relatively small. It has been used for decades to encapsulate mainly flavors, lipids and pigments, but its use in thermosensitive products such as microorganisms and essential oils can be limited due to the use of high temperatures which causes product volatilization and / or destruction (GHARSALLOUI et al., 2007).

Pereira (2007) investigated the efficiency of chitosan as a wall material in the microencapsulation process of the phyto-constituent eugenol by means of the spray drying method and verified that the biopolymer was efficient in the microencapsulation process, and this technique could be considered as a viable alternative in the encapsulation of volatiles.

Santos, Favaro-Trindade and Grosso (2005) evaluated the microencapsulation of paprika oleoresin by spray drying using encapsulating agents (gum arabic and porous starch / gelatin granules). The production of microcapsules of paprika oleoresin with the encapsulating agents was successful as it was able to protect the carotenoids against factors that cause oxidation of this pigment.

Carmona (2011) confirmed in his study that the process of obtaining orange oil microparticles by spray drying was fast and simple to perform.

Felix (2014) sought to evaluate the efficiency of the microencapsulation of cinnamaldehyde (cinnamaldehyde major essential phytoconstituent) with wall materials (gum arabic and protein isolate). All wall materials and combinations thereof associated with maltodextrin proved to be amenable to the microencapsulation of the volatile compound.

In the study by Carvalho (2009), when evaluating the encapsulation of oregano essential oil, it was able to confirm that the spray drying process was effective in the retention of the active compound, referring it as a viable technique.

According to Garcia (2013), there was an expressive increase in retention of basil essential oil by the microencapsulation technique in question, taking into account all wall materials (a combination of gum arabic, maltodextrin plus soy protein isolate and maltodextrin more whey protein concentrate) used, it is emphasized that this retention was optimized with increasing homogenization pressure.

Müller (2011) showed high efficiency of encapsulation in orange essential oil (99.32\%), even after 10 months of storage, the microcapsules kept the oil concentrations stable.

In agreement with Garcia (2013), Frascareli (2010) to microencapsulate the coffee essential oil under high pressure in the homogenization, verified that the emulsions fed in the spray drying were stable, with smaller particle diameter and with less dispersion of the distribution.

\section{Complex Coacervation:}

Complex coacervation can be defined as a process in which a polyelectrolyte complex is formed.This process requires the mixing of two colloids, with $\mathrm{pH}$ adjustment. The two oppositely charged polymers are driven to a phase separation and formation of solid particles or closed liquid droplets (CHÁVARRI, MARAÑ́N and VILLARÁN, 2012).

In the food industry, this technique has been used for the encapsulation of several active food components such as: flavorings, probiotics, oils, nutrients, vitamins and enzymes (GOUIN, 2004; FANG and BHANDARI, 2010; AUGUSTIN and HEMAR, 2009; ALVIM and GROSSO, 2010).

The complex coacervation technique presents numerous advantages when compared to other techniques including: versatility, efficient control in particle size, possibility of using biopolymers with absence of organic solvents and soft conditions of processing temperature (MENEZES et al., 2013; JAMEKHORSHID, SADRAMELI and FARID, 2014). However, one of the limitations of complex coacervation is the difficulty of encapsulation of hydrophilic 
compounds, the most appropriate technique being the incorporation of hydrophobic compounds (MENDANHA et al., 2009; SILVA et al, 2015).

The coacervation technique was performed by Yang et al. (2015). This study aimed to improve the stability of poppy seed oil and used gum arabic and gelatin as wall materials. The microcapsules showed good performance for the incorporation of the oil of poppy seeds, which possibly can be used in the food industries.

Comunian et al. (2013) used complex coacervation in ascorbic acid encapsulation. The researchers evidenced high values obtained in the encapsulation efficiency (between $97.33 \pm 0.81$ and $99.57 \pm 0.32 \%$ ) of the compound, proving the efficiency of this technique against the said active agent.

In the study of Gonçalves (2016), it was possible to prove the efficiency of the same technique by microencapsulating the essential oil of thyme using gelatine/gum arabic as wall materials.The encapsulation efficiency was about $85.3 \%$ of the oil. Müller (2011) also obtained high values $(99.49 \%)$ for the efficiency of the encapsulation of the orange essential oil through this system.

The values of buriti oil encapsulation efficiency through this technique revealed similarity with tests performed in other studies, obtaining results close to $80 \%$ (LEMOS, 2017).

Santos et al. (2015) opted for the coacervation technique to produce and characterize xylitol microcapsules for use in foods in order to prolong the sweet and refreshing effect provided by this ingredient and found that the encapsulation efficiency was relatively good in the case of a hydrophilic core, in addition, more than $70 \%$ of microencapsulated xylitol was released in artificial saliva over a period of 20 minutes.

Souza (2016) chose to encapsulate the cinnamon extract by the same technique and concluded that the encapsulated extract particles showed resistance when subjected to stress conditions and provided good stability of the encapsulated phenolic compounds during drying.In addition, the encapsulation process was able to mask undesired sensory characteristics, such as strong taste and astringency sensation caused by proanthocyanidins.

\section{Fluidized bed:}

According to Tewes, Boury and Benoit (2006), the fluidized bed encapsulation process basically consists of adding the components of the formulation to be prepared in a fluidized bed reactor, where a high velocity hot air stream is forced into through the solid particles of the active agent to be encapsulated, thereby forming the fluidized bed.In the inner part of the coating chamber, the solid particles of the core are coated by spray, dispersion or emulsion of the wall material or even of a melt, by controlled variables (humidity and temperature).

Generally, the fluidized bed may be used in the agglomeration of particles or in the production of particles, granulates, coated tablets and capsules (PARIKH, 1991).

This technique may contribute to the improvement of the characteristics of dry extracts due to the formation of granules with adequate fluidity, compressibility, appearance and uniformity, masking undesirable flavors and odors, or protecting against degradation by exposure to oxygen, light, moisture, $\mathrm{pH}$ and incompatible agents (SALEN and GUIGON, 2007; FÁVARO-TRINDADE, PINHO and ROCHA, 2008; LEE and SHIN, 2009; BENALI, GERBAUD and HEMAD, 2009).

Fluidized bed encapsulation also has other advantages such as: high degrees of contact between the two phases, heat and mass exchange, and degree of mixing within the dryer.In addition to ease of process monitoring, being considered an economically viable technique and ideal for thermosensitive products (LEE and SHIN, 2009).

However, there are some difficulties with this technique, among the main ones are: the defluidization, which occurs due to the formation of large particle agglomerates, drastically altering the dynamic activity of the system, and the phenomenon of friction that can generate losses of the material reducing the efficiency of the encapsulation (HEMATI et al., 2003). 
There are several fluidized bed configurations for the atomization of the feed composition: the air suspension system or Wurster system, with bottom-spray feed, top-spray system) and system with tangential feed to the particle bed (BENELLI et al., 2015).

Fluidized bed coating processes are widely used in a number of industrial segments, including food and agriculture.These operations include: mixing, drying, coating, granulation, obtaining controlled release systems, among others (MURTHY and JOSHI, 2007; DIXIT and PUTHLI, 2009; FUKUMORI and ICHIKAWA, 2007).

A study by Benelli et al. (2015) analyzed the coating/agglomeration process of rosemary(Rosmarinus officinalis) extract in fluidized bed with top spray atomization using particle seeds of natural origin (cassava flour and sugar pellets).Granules with excellent fluidity and high retention of phenolic compounds were obtained, confirming the viability of the fluidized bed as a promising method for the production of herbal compositions with appropriate physicochemical and pharmacotechnical properties.

In the application of the fluidized bed to coat the carnauba wax particles, Paulo (2017) used the following polysaccharides as a wall material: sodium alginate, gum arabic, chitosan, maltodextrin and Eudragit ${ }^{\circledR}$ L30-D55 and emphasized the importance of evaluating parameters as contact angle and viscosity for the selection of wall materials when using this type of technique, since only the suspensions containing Eudragit ${ }^{\circledR}$ L30-D55 and sodium alginate had the lowest contact angle $\left(\theta \cong 40^{\circ}\right)$, low viscosity and were able to cover the carnauba wax particles (coating efficiency $\cong 55 \%$ ).

Cardoso, Grosso and Vitali (2001) prepared microcapsules containing fish oil coated in a fluidized bed, and the encapsulation yields of the retained oil were high, being $88.9 \%$ in the particles covered with gelatin and $85.9 \%$ in the particles coated with calcium pectate.The highest yield obtained for gelatin coverage is possibly due to the use of only one spray system.

\section{Freeze-drying:}

Freeze-drying, also known as cryosecting or freeze-drying, is a process characterized by dehydration, so that the water or other solvent of the previously frozen product passes from the solid to the gaseous state (sublimation) in conditions of temperature and pressure. In this technique, in order for the water to pass directly from the solid to the vapor phase, the temperature and the partial pressure of water vapor must be lower than the triple point, ie $0.0099^{\circ} \mathrm{C}$ and 4.58mmHg (BOSS, 2004; PEREDA, 2005).

Basically, the lyophilization system is formed by a vacuum chamber, a condenser, a compressor and the vacuum pump. The condenser, in the form of streamers, condenses the vapor released by the product into ice and the vacuum pump removes non-condensible vapors. This technique has three distinct stages: initial freezing stage, primary drying and secondary drying (PEREDA, 2005; MARQUES, 2008).

In the first stage, freezing of the product to be lyophilized, should generally be below a temperature of $-18^{\circ} \mathrm{C}$. This phase is of paramount importance for the quality of the final product and the performance of the lyophilization, since the size and homogeneity of the formed ice crystals characterize the shape, distribution, size and connectivity of the formed dry layer by sublimation, thus influencing the parameters that define heat transfer and mass in the product during primary and secondary drying (PEREDA, 2005; MARQUES, 2008).

In the primary drying, the frozen water is removed by sublimation, giving empty spaces inside the lyophilized product that were previously occupied by the ice.For this to happen, it is necessary to keep the frozen material below $-10^{\circ} \mathrm{C}$ and absolute pressure of $2 \mathrm{mmHg}$ or less. At this stage, most of the water is removed, around $90 \%$ of the initial content (MARQUES, 2008; PEREDA, 2005).

And in secondary drying, after sublimation, significant amounts of bound water can still be left inside the product, requiring an additional potential. The driving force of this stage is heating (the temperature increases between 20 and $50^{\circ} \mathrm{C}$ ), where the desorption of water occurs, with the final humidity reaching 2 to $10 \%$ (SNOWMAN, 1997; PEREDA, 2005; MARQUES, 2008).

Lyophilization has several advantages when compared to other drying processes which also use drying, i.e., drying at high temperatures, at ambient pressure and without prior freezing. The advantages include: lower product 
contraction, higher solubility (due to the spongy structure left by the water outlet), avoids decomposition by heat, promotes the reduction of volatile loss without influencing product quality, as well as reduces enzymatic actions of microorganisms, prevents protein denaturation, and preserves the initial morphology of the material (ORREGO, 2008).

Despite the numerous advantages, this drying system also has some limitations, such as its long life The causes of this limitation are mainly due to the low heat transfer performance inside the product and the reduced working pressures, which make the radiation the main mechanism of heat transfer, since, there is little convection and a low conduction between the surfaces of vacuum contact (HAMMAMI and RENÉ, 1997).

Another limiting factor is the high cost to use this technique, since it has a relatively low drying rate, generating high energy consumption for sublimation and for the removal of water vapor from the chamber (KOROSHI, 2005).

As for indications, this technique is commonly indicated for thermosensitive materials such as: biological materials (fungi, enzymes, tissues), pharmaceutical materials (antibiotics, vaccines, serums) and foods (juices, meats, vegetables, fruits) temperatures and basically work under vacuum, promotes the generation of products with superior quality when compared to those obtained through other drying techniques (MARQUES, 2008).

In the food context, this system provides high retention of the sensory characteristics and nutritional quality of the food, in addition to increasing the shelf life when properly packaged.Depending on the food, storage at room temperature is possible. The volatile aromatic compounds are not absorbed by water vapor and are retained in the food matrix, with a possible retention of 80 to $100 \%$ of the food flavor.Furthermore, it facilitates the transportation process, due to the lightness of the product obtained and because it does not require refrigeration, leading to a lower transportation cost (EVANGELISTA, 2005).

Desobry et al. (1997) reported that lyophilization encapsulation resulted in lower degradation of $\beta$-carotene during the process $(8 \%)$. In contrast, its high cost and long process time hamper its commercial applicability.

\section{Ionic Gelation:}

This technique is based on the ability of anionic polysaccharides (such as alginate, pectin, carrageenan gum and gellan gum) to gel in the presence of ions such as calcium (BUREY et al., 2008; SILVA et al., 2006). The mechanisms of ionic gelling for the production of particles have been performed, mainly by two processes: internal and external gelation.

\section{Internal Gelling:}

The internal ionic gelation forms particles by the addition of calcium salts, directly in the polymer solution containing inclusion material. The ionic gelation occurs after reduction of $\mathrm{pH}$, with the addition of an acidic solution in the water-in-oil emulsion, to release the calcium ions, allowing the complexation of calcium with the carboxylic groups. The emulsions formed may be water-in-oil (W/O), oil/water $(\mathrm{O} / \mathrm{W})$ or oil/oil $(\mathrm{O} / \mathrm{O})$ (Figure 2) (HELGERUD et al., 2009; SCHOUBBEN et al., 2010; SMRDEL et al., 2008). In both cases, the so-called internal phase, to which the polymer is dissolved, is an organic solvent having a limited solubility in the outer phase of the emulsion, which may be water, forming an emulsion. An insoluble or partially insoluble calcium salt is previously present inside the emulsion droplets. An acid is then added to the medium which propagates along the continuous phase into the droplets. The $\mathrm{pH}$ reduction occurs and $\mathrm{Ca}^{+2}$ ions are released following gelation (PONCELET, 2001; O'DONNELL and MCGINITY, 1997; CHAN, LEE and HENG, 2006). 
Figure 2:-Different stages of preparation of alginate capsules by the internal ionic gelation method
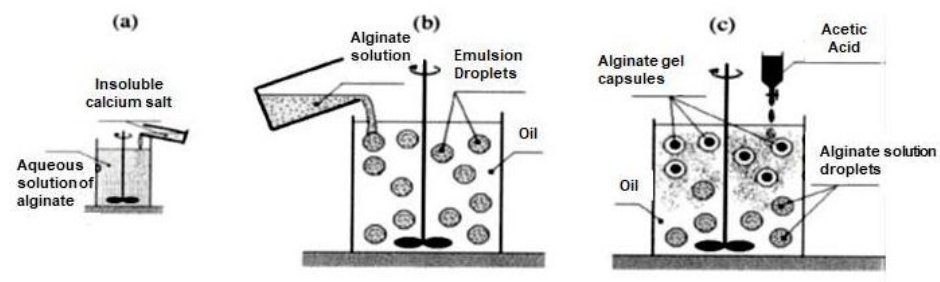

(d)
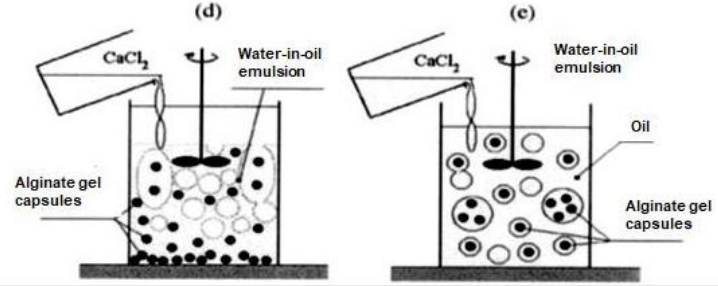

Source: Adapted from Poncelet et al., 1999.

Through ionic gelling, carbohydrate-rich protein diets can be produced, as well as incorporating hydrophobic particles in their composition with the use of hydrocolloids, acting efficiently as an impermeable matrix for oxygen, acidity and certain organic compounds (MUKAI-CORRÊA et al., 2004; LUPO et al., 2014).

In the food industry, the most commonly used hydrocolloids are alginate and pectin, naturally occurring hydrophobic polyelectrolytes with an advantageous membrane biocompatibility and absence of interfacial tension with fluids (VOS et al., 2010; TEIXEIRA et. al., 2014; CHAN, LEE and HENG, 2006).

Cho, Shim and Park (2006) microencapsulated fish oil into double emulsions obtained by the gelling technique. Initially, an oil-in-water emulsion was produced by dispersing the fish oil into soy protein isolate. This emulsion was subsequently dispersed in corn oil to form a double o/w/o emulsion. To initiate gelation the enzyme transglutaminase. The resulting microcapsules showed spherical structures with an average diameter of $23 \mu \mathrm{m}$. In general, this method improved the stability of the active agents and enabled the controlled release.

Laine et al. (2011) microencapsulated rapeseed oil through emulsification (oil in water) using modified oat bran. The researchers found that among the independent variables, the bran content had a greater effect on the emulsion properties, although there was a reduction in viscosity and homogenization pressure. With this result, it could be stated that the modified oat bran has an excellent ability to form stable emulsions which may be suitable for this microencapsulation technique.

In the study by Sarkar et al. (2012), microcapsules of mint oil with gum arabic and guar gum (irradiated) were produced by emulsification followed by spray-dryer. The microcapsules were analyzed for retention of mint oil over the 8 week period. The results obtained demonstrated that guar gum irradiated at 50kGy can be used in the partial substitution of gum arabic for encapsulation of sensitive food ingredients, since in this condition there was greater retention during storage period.

Lupo et al. (2014) microencapsulated polyphenols extract by internal ionic emulsification / gelation and reported that the microcapsules of citrate and carbonate salts had a smaller diameter and an encapsulation efficiency of $60 \%$. They concluded that the microparticles of cocoa could increase the daily intake of antioxidants when implemented in a food product.

Holkem, Codevilla and Menezes (2015) have stated that the emulsification using double emulsion is being used extensively in the encapsulation of oils since it favors a better protection for the active agents. The emulsions may be water-oil-water (w/o/w) or oil-water-oil (o/w/o). 


\section{External Ionic Gelation:}

In the external ionic gelation a solution of biopolymer containing the material of interest is dripped onto an ionic solution at appropriate concentrations and considerable levels of encapsulated active agent and particles of different shapes and sizes can be achieved (Figure 3). The interactions of the ions with the carboxylate groups of polysaccharides lead to the formation of insoluble gels (ARANHA, 2015).

The hardening of the particles occurs rapidly, starting at the surface, in which the divalent ions react with the negatively charged biopolymer chains, this results in the formation of a rigid three-dimensional structure, with high water content, through which the ions diffuse into the particle, providing the cross-linking from the outer part to the inner part (SMRDEL et al., 2008; HELGERUD et al., 2009; SCHOUBBEN et al., 2010).

Figure 3:-Particle production by external ionic gelation

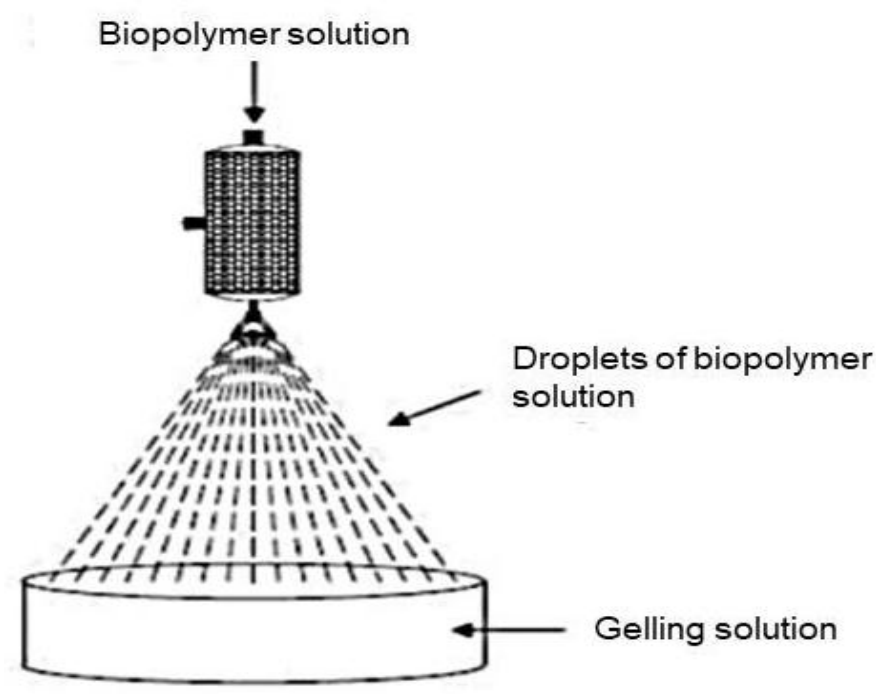

Source:-Adapted from Aranha, 2015.

The ionic gelling particles can be produced by extrusion and atomization. By extrusion, the solution with the wall material and active agent is dripped into an ionic solution through a needle, with or without controlled speed. In the atomization, the compressed air mixes with the solution to be encapsulated, pressing the exit of the solution through a orifice of controlled size (BUREY et al., 2008; PATIL et al., 2010).

Ionic gelling is a simple technique, which does not require the use of organic solvents, $\mathrm{pH}$ or extreme temperature, making it low cost when compared to other encapsulation systems.In addition, it enables the encapsulation of hydrophilic or hydrophobic substances (MCCLEMENTS, 2005). In contrast, although the ionic gelling particles are suitable for encapsulation, they are sensitive to extreme $\mathrm{pH}$ values. There is also another limiting factor which is the porosity of the matrix which generates the release of the encapsulated substance. In order to overcome this drawback, the structure of the gel can be changed by combining various types of biopolymers in order to assure the advantage of the chemical composition of each compound or to promote its interaction with polyelectrolytes, the proteins (PATIL et al., 2010).

Gelling/emulsification is applied in various fields such as: pharmaceutical, medical and agronomic. In the food sector it is considered promising and several studies have been carried out (LAM and GAMBARI, 2014).

A study carried out the microencapsulation by external ionic gelation associated with the electrostatic interaction of the dye extracted from the buriti pulp, using the alginate coating materials: whey proteins (WPC) and pectin: whey proteins (WPC). The gelation process was effective in the encapsulation of buriti oil, although the alginate: WPC particles presented a more regular shape and a smoother surface when compared to those of pectin: WPC, which showed more rough surfaces and elongated forms (ARANHA, 2015). 
Silva (2016) produced alginate and gelatin microgels by ionic gelation to protect probiotics (Lactobacillus acidophilus) and also evaluated the influence of the addition of Fructooligosaccharides (FOS) on the encapsulation matrix.The study revealed that microgels were efficient against the protection of microorganisms, the survival and viability of probiotics during the microencapsulation process, resistance to digestive fluids by in vitro simulation and stability to storage under controlled conditions.

Rocha (2017) produced microparticles containing tomato juice via external ionic gelation in order to evaluate the combination of carrier materials (inulin and maltodextrin together with sodium alginate). Through the results, it was concluded that the wall material, alginate and inulin provided better protection over time, demonstrating the possibility of producing alginate microparticles containing tomato juice.

\section{Liposomes:}

Liposomes have one or more concentric layers of lipids, usually phospholipids, forming microscopic vesicles, which provide a barrier to diffusion of the solute (SAKATA et al., 2007). These vesicles may encapsulate hydrophobic, hydrophilic and amphiphilic materials, depending on their lipid composition. Liposomes have received a reputation for their potential application as a coating of drugs (including bioactive macromolecules). Recently, the use of liposomes by the food industry has been proposed, especially for the encapsulation or immobilization of enzymes (JUVERIYA et al., 2016).

The use of liposomes as a way of controlled release of flavorings, pigments and natural active agents through the liposomes is considered a promising alternative because of its protection capacity, against several conditions associated with the food matrices and elaboration processes involved, besides to increase the availability and bioactivity of these compounds (CHAPAL, 2017).

Several studies have reported the importance of using liposomes as a food encapsulation technique, with the encapsulation of ascorbic acid and tocopherol that were loaded into liposomes and then incorporated into apple juice, orange juice and dairy products improving its bioactivity (MARSANASCO et al., 2011; WECHTERSBACH et al., 2012).

The encapsulation of fish oil in a liposomal system by the ethanol injection method inhibited some undesirable attributes of this compound (such as odor), resulting in a high-omega-3 food supplement (AMNUAIKIT et al., 2016).

The inclusion of quercetin in liposomes made from soybean phospholipids and coated with Isolated Whey Protein (WPI) was evaluated for application in a functional milk beverage, revealing that the coated liposomes allowed to mask the undesirable sensory characteristics of the active compound in addition, the coating allowed a greater stability of the liposomes by protecting them from the osmotic forces arising from the significant amounts of sugars and salts present in the beverage, preserving the stability under refrigeration temperature in the course of three months(FRENZEL and STEFFEN-HEINS, 2015).

The encapsulation of polyphenols obtained from grape seed extract in chitosan-coated liposomes provided greater control in the release of polyphenols, retaining their bioactivity for a prolonged period when compared to the encapsulation in simple liposomes and with the free compound, these liposomes originated a system with greater stability, which allowed its use in food of high water content (GIBIS et al., 2016).

Liolios et al. (2009) evaluated the antioxidant capacity, antimicrobial activity (on Gram negative and positive bacteria) and pathogenicity against Listeria monocytogenes (present in some foods) of a liposomal system based on phosphatidylcholine of carvacrol and thymol (compounds obtained from the essential oil of Origanum dictamnus L.).The results showed higher antioxidant capacity and antimicrobial activity of these encapsulated compounds when compared to their pure form.It should be noted that thymol was a more potent antimicrobial than carvacrol against most of the microorganisms tested. The same result was obtained with the use of clove essential oil encapsulated in liposomes made from soy lecithin and cholesterol.This system improved the chemical stability of the essential oil, thus increasing its antimicrobial action time against Staphylococcus aureus in tofu (CUI et al., 2015). These results contribute to the promising use of this type of compound as a preservative in the food industry (CHAPAL, 2017). 


\section{Molecular inclusion - cyclodextrins:}

This process occurs at the molecular level, unlike the other described techniques, generally using the cyclodextrins (CD) as encapsulating material.The $\mathrm{CD}$ are cyclic carbohydrates consisting of $6(\alpha-C D), 7(\beta-C D), 8(\gamma-C D)$ or more $\alpha$ - $(1,4)$ linked glycopyranic units. In general, this technique is used to encapsulate compounds like vitamins, aromas, essential oils, dyes, among others (MARTIN DEL VALLE, 2004; BRASILEIRO, 2011). The oligosaccharide commonly used in these complexes is $\beta$-cyclodextrin, which in turn acts as a molecular capsule, with a polar outer surface and an apolar cavity, which makes it capable of playing the role of "host molecule", forming inclusion complexes with large variety of low polarity "guest molecules" (MARTIN DEL VALLE, 2004).

Molecular encapsulation is based on the substitution of water molecules that have high enthalpy, by smaller enthalpy molecules. It is an energetically viable process, because it allows the favorable alteration of enthalpy, increase of entropy and reduction of the total energy of the system, factors that favor the increase of the stability of the formed complex.Other factors that also contribute to the formation and stabilization of inclusion complexes are: Van der Waals electrostatic interactions, hydrophobic interactions and hydrogen bonds (LYRA et al., 2010; EVANGELISTA, 2010). The inclusion in CD directly influences the characteristics of the guest molecules, among them: increased solubility, increased oxidative stability, stabilization of emulsions, control of volatility and control of the release of flavors (DEL VALLE, 2004).

The technique does not require the use of specific equipment of high cost, in contrast, a limiting factor is the high economic value of CDs (POTHAKAMURY, 1995; AZEREDO, 2005).

Studies have shown that CD not only masks the taste of essential oils to be used as antimicrobial agents, but also protects against the oxidation triggered by high temperatures, which allows the use of these oils, preserving their effectiveness as an antimicrobial agent in a wide variety of environmental conditions and for long periods of time (DUCHÊNE, 1987; SZEJTLI, 1998).

According to Szente and Szejtli (1986), the molecular inclusion in $\beta$-CD was efficient in reducing the loss of coffee volatiles. Matioli and Rodriguez-Amaya (2003), when encapsulating a pigment (lycopene), found that the higher the ratio of $\gamma-\mathrm{CD}$, the greater the color intensity of the final product. And even in the presence of light, the stability of the complex was considered excellent.

Lying, Passos and Fontana, (2005) carried out a study in order to form an inclusion complex between $\beta$-cyclodextrin and bixin (carotenoid) and to define its stability under different established conditions. The results evidenced that the pure bixin extract lost $26 \%$ of the color being protected from light and in contact with oxygen for six weeks, while the encapsulated sample obtained a reduction of only $1.4 \%$, which allowed greater protection of the pigment.

Kuck (2016) microencapsulated polyphenols extracted from the bark of the Isabel and Bordô grapes, using different wall materials. The extracts were submitted to atomization to obtain the microparticles, using gum arabic, $\beta$ cyclodextrin and hydroxypropyl- $\beta$-cyclodextrin as encapsulating agents, combined in maximum concentrations of $5 \%$. The results showed that the treatment prepared with $3 \%$ gum arabic and $2 \% \beta$-cyclodextrin was considered the best, with a higher retention of flavonoids $(67.2 \%)$, showing that the inclusion complexes present good retention capacity volatile agent.

\section{Conclusions:-}

The technology of microencapsulation of food ingredients and other substances has been shown to be highly employable, since it is an effective strategy and of great relevance in the conservation of various nutritional components, microorganisms, enzymes, colorants, flavorings, sweeteners, among others, protecting them from degradation and increasing stability, due to its advantageous characteristics which consequently results in products with superior quality.Thus, it can be considered that microencapsulation has a high potential to expand the market for high value-added products, producing foods that are not only a source of nutrients with sensory appeal, but also a means of well-being and health for consumers. 


\section{References:-}

1. Albini, 1. T. Solubilidade do biopolímero plc em solventes para aplicação no processo de microencapsulação. 2012.88f. Dissertação (mestrado em engenharia de alimentos), Universidade Federal do Paraná, Paraná, 2012.

2. Alvim, i. D.; grosso, c. R. F. Microparticles obtained by complex coacervation: influence of the type ofreticulation and the drying process on the release of the core material. Ciênc. Tecnol. Aliment., Campinas, v. 30, n. 4, p. 1069-1076, 2010.

3. Amnuaikit, t. Formulation development and preparation of fish oil liposome by using high pressure homogenizer for food supplement product. Asian jornal of pharmaceutical sciences, v.11, p.126-127, 2016.

4. Anal, a. K.; singh, h. Recent advances in microencapsulation of probiotics for industrial applications and targeted delivery. Trends in food science \& technology, v. 18, n. 5, p. 240-251, 2007.

5. Anconi, c.p.a.; nascimento jr, c.s.; de almeida, w.b.; dos santos, h.f. Theoretical study of covalently bound $\alpha-$ cyclodextrin associations. The journal of physical chemistryc, v. 116, p.18958-18964, 2012.

6. Anson, r. Microencapsulation: for enhanced textile performance. Performance apparel markets, v.12, p.21-39, 2005.

7. Aranha, c. P. M. Microencapsulação por gelificação iônica e interação eletrostática do corante de buriti (mauritia flexuosa 1. F.). 2015. 177 f. Tese (doutorado) - Universidade Estadual Paulista "Júlio de Mesquita Filho", São José do Rio Preto, 2015.

8. Augustin, m. A.; hemar, y. Nano and microstructured assemblies for encapsulation of food ingredientes. Chem. Soc. Rev, v. 38, p. 902-912, 2009.

9. Augustin, m.a.; sanguansri, 1.; margetts, c.; young, b. Microencapsulation of food ingredients. Food australia, v.53, n.6, p.220-223, 2001.

10. Azeredo, h. M. C. Encapsulação: aplicação à tecnologia de alimentos. Alimentos e nutrição, v. 16, n. 1, p. 8997, 2005.

11. Barreto, b. N. Obtenção e caracterização de microcápsulas de óleo vegetal por gelificação do sistema quitosana/tripolifosfato de sódio. 2008.101f. Dissertação (ciência e tecnologia de polímeros) - Instituto de Macromoléculas Professora Eloisa Mano, Universidade Federal do Rio de Janeiro, Rio de Janeiro, 2008.

12. Benali, m.; gerbaud, v.; hemad, m. Weffect of operatinh conditions and physicochemical properties on the wet granulation kinetics in hight shear mixer. Power technology, v. 190, n. 1-2, p. 160-169, 2009.

13. Benelli, 1.; cortés-rojas, d.f.; souza, c.r.f.; oliveira, w.p. Fluid bed drying and agglomeration of phytopharmaceutical compositions. Powder technology, v. 273, p. 145-153, 2015.

14. Boss, e.a. Modelagem e otimização do processo de liofilização: aplicação para leite desnatado e café solúvel. 2004.107f. Tese (doutorado em engenharia química)- Faculdade de Engenharia Química, UNICAMP, Campinas, 2004.

15. Brasileiro, j.s.l. Microencapsulação de compostos bioativos: inovação em diferentes áreas. $2011.71 \mathrm{f}$. Dissertação (mestrado integrado em ciências farmacêuticas)- Faculdade de Ciências da Saúde. Universidade Fernando Pessoa, Porto, 2011.

16. Burey, p.; bhandari, b.r.; howes, t.; gidley, m.j. Hydrocolloid gel particles: formation, characterization, and application. Critical reviews in food science and nutrition, v. 48, n. 5, p. 361-377, 2008.

17. Cardoso, f. S. N.; grosso, c. R. F.; vitali, a. Microcápsulas de amido obtidas através da secagem por atomização e recobertas em leito fluidizado. Brazilian journal of food technology, Campinas, v. 4, n. 69, p. 131-136, 2001.

18. Carmo, e. L. D.; fernandes, r. V. D. B.; barros, r. V.; borges, s. V. Encapsulação por spray drying, novos biopolímeros e aplicações na tecnologia de alimentos. Journal of chemical engineering and chemistry, v. 1, n. 2 , p. 30-44, 2015.

19. Carmona, p. A. O. Secagem por atomização e microencapsulação de óleo de laranja: estudo das propriedades da emulsão e do tipo de material de parede sobre as características do pó e a estabilidade de d-limoneno. 2011. 176f. Dissertação (mestrado em engenharia de alimentos) - Faculdade de Engenharia dos Alimentos, Universidade Estadual de Campinas, Campinas, 2011.

20. Carneiro, h. C. F. Microencapsulação de óleo de linhaça por spray drying: influência da utilização de diferentes combinações de materiais de parede. 2011.113f. Dissertação (mestrado em engenharia dos alimentos) Faculdade de Engenharia dos Alimentos, Universidade Estadual de Campinas, Campinas, 2011.

21. Carvalho, j. S. R. Encapsulamento de óleo essencial de origanum virens 1. Em matrizes de gelatina e gelatina/sacarose. 2009.90f. Dissertação (mestrado em engenharia alimentar) - Instituto Superior de Agronomia, Universidade Técnica de Lisboa, Lisboa, 2009.

22. Chan, 1. W.; lee, h. Y.; heng, p. W.s. Mechanisms of external and internal gelation and their impact on the functions of alginate as a coat and delivery system, carbohydrate polymers, v.63, n.2, p.176-187, 2006. 
23. Chapal, j.c.a.desenvolvimento e caracterização de um sistema lipossomal para a encapsulação de eugenol. 2017.44f. Dissertação (mestrado em ciência e tecnologia de alimentos) - Universidade Federal de Viçosa, Minas Gerais, 2017.

24. Chávarri, m., marañón, i.; villarán, m. C. Encapsulation technology to protect probiotic bacteria. Intechopen, p. 1-41, 2012. Disponível em: <https://www.intechopen.com/books/probiotics/encapsulation-technology-toprotect-probiotic-bacteria>. Acesso em 24 de novembro de 2018.

25. Chew, s. C.; tan, c.p.; long, k.; nyam, k.l.in-vitro evaluation of kenaf seed oil in chitosan coated-high methoxylpectinalginate microcapsules. Industrial crops and products, v. 76, p. 230-236, 2015.

26. Cho, y.h., shim, h.k., park, j. Encapsulation of fish oil by an enzymatic gelation process using transglutaminase cross-linked proteins, journal of food science, v. 68, p. 2717-2723, 2006.

27. Comunian, t. A.; thomazini, m.; alves, a.j.g.; matos junior, f.e.; balieiro, j.c.c.; favaro-trindade, c.s. Microencapsulation of ascorbic acid by complex coacervation: protection and controlled release. Food research international, v. 52, p. 373-379, 2013.

28. Coman, m. M.; cecchini, c.; verdenelli, m. C.; silvi, s.; orpianesi, c.; cresci, a. Functional foods as carriers for synbioß, a probiotic bacteria combination. International journal of food microbiology, v. 157, n. 3, p. 346-352, 2012.

29. Cui, h.; zhao, ch.; lin, 1. The specific antibacterial activity of liposome Encapsulated clove oil and its application in tofu. Food control, v.56, p.128-134, 2015.

30. Depypere, f.; verbeken, d.; thas, o.; dewettinck, k. Mixture design approach on the dynamic rheological and uniaxial compression behaviour of milk desserts. Food hydrocolloids, v. 17, n. 3, p. 311-320, 2003.

31. Del valle, e. M. M. Cyclodextrins and their uses: a review. Process biochemistry, v.39, n. 9, 2004. 1033-1046.

32. Desobry, s.a.; netto, f.m.; labuza, t.p. Comparison of spray-drying, drum-drying and freezedrying for -carotene encapsulation and preservation. J. Food sci., v.62, n.6, p.1158-1162, 1997.

33. Dixit, r.; puthli, s. Fluidization technologies: aerodynamic principles and process engineering. Journal of pharmaceutical sciences, v. 98, n. 11, p. 3933-3960, 2009.

34. Duchêne, d. Cyclodextrin and their industrial uses. Paris: editions de santé, 1987.

35. Etchepare, m. A.; raddatz, g.c.; flores, e.m.m.; zepka, l.q.; jacob-lopes, e.; barin, j.s.; grosso, c.r.f.; menezes, c.r. Effect of resistant starch and chitosan on survival of lactobacillus acidophilus microencapsulated with sodium alginate. Food science and technology, v. 65, p. 511-517, 2016.

36. Evangelista, b.a.l. Caracterização, análise físico-química e estabilidade térmica do complexo de inclusão clicodextrina-17- valerato de betametasona. 2010.110f. Dissertação (mestrado em fármaco e medicamentos) Universidade de São Paulo, São Paulo, 2010.

Evangelista, j. Tecnologia de alimentos. 2ed. São paulo: atheneu, 2005.

37. Fang, z.; bhandari, b. Encapsulation of polyphenols - a review. Trends in food science \& technology, v. 21 , p. 510-523, 2010.

38. Farias, m. C.; moura, m. L.; andrade, 1.; leão, m. H. M. R. Encapsulation of the alpha-tocopherol in a glassy food model matrix. Materials research. V. 10, n.1 p. 57-62, 2007.

39. Favaro-trindade, c. S.; pinho. S. C.; rocha, g. A. Revisão: microencapsulação de ingredientes alimentícios. Brazilian journal of food technololy, v.11, p.103-112, 2008.

40. Favaro-trindade, c. S.; heinemann, r.j.b.; pedroso, d.1. Developments in probiotic encapsulation. Cab reviews: perspectives in agriculture, veterinary science. Nutrition and natural resources, v. 6. P. 1-8, 2011.

41. Felix, p. H. C. Microencapsulação de óleo essencial de canela por atomização com emprego de diferentes materiais de parede. 2014. 92f. Dissertação (mestrado em engenharia química) - Escola de Engenharia, Universidade Federal de Minas Gerais, Minas Gerais, 2014.

42. Fernandes, r. V. B. Microencapsulamento de óleo essencial de alecrim (rosmarinus officinalis 1.) Através de secagem por atomização. 2013. 134f. Dissertação (mestrado em ciências dos alimentos) - Universidade Federal de Lavras, Minas Gerais, 2013.

43. FIB (Food Ingredients Brasil). Microencapsulação - a tecnologia da microencapsulação de ingredientes, n.42, 2017. Disponível em: <http://revista-fi.com.br/upload_arquivos/201711/2017110261764001512044051.pdf>. Acesso em 21 de novembro de 2018.

44. Frascareli, e. C.; silva, v. M.; tonon, r. V.; hubinger, m. D. Effect of process conditions on the microencapsulation of coffee oil by spray drying. Food and bioproducts processing, v. 90, n. 3, p. 413-424, 2012.

45. Frascareli, e. C. Microencapsulação de óleo de café através de secagem por atomização: avaliação das propriedades da emulsão e do tipo de material de parede sobre as características do pó. 2010.181f. Dissertação 
(mestrado em engenharia dos alimentos) - Faculdade de Engenharia dos Alimentos, Universidade Estadual de Campinas, Campinas, 2010.

46. Frenzel, m. E steffen-heins, a. Whey protein coating increases bilayer rigidity and stability of liposomes in food-like matrices. Food chemistry, v.173, p.1090-1099, 2015.

47. Garcia, 1. C. Microencapsulação por spray drying de óleo essencial de manjericão. 2013. 2017f. Tese (doutorado em engenharia dos alimentos) - Faculdade de Engenharia de Alimentos, Universidade Estadual de Campinas, Campinas, 2013.

48. Gharsallaoui, a.; roudaut, g.; chambin, o.; voilley, a.; saurel, r. Applications of secagem por spray in microencapsulation of food ingredients: an overview. Food research international, v. 40, n. 9, p. 1107-1121, 2007.

49. Gibis, m.; ruedt, ch.; weiss, j. In vitro release of grape-seed polyphenols encapsulated from uncoated and chitosan-coated liposomes. Food research international, v. 88, p.105-113, 2016.

50. Gonçalves, n. D. Encapsulação de óleo essencial de tomilho e avaliação como potencial ingrediente funcional tecnológico. 2016. 90f. Dissertação (mestrado em ciências da nutrição e do esporte e metabolismo) - Faculdade de Ciências Aplicadas, Universidade Estadual de Campinas, Limeira, 2016.

51. Gouin, s. Microencapsulation: industrial appraisal of existing technologies and trends. Trends in food science \& technology, v. 15, p. 330-347, 2004.

52. Grosso, f. S. N. C. C.; vitali, a. A. Microcápsulas de amido obtidas através da secagem por atomização e recobertas em leito fluidizado. Brazilian journal food technology, n. 4, p. 131-136, 2001.

53. Hammami, c.; rené, f. Determination of freeze-drying process variables for strawberries. Journal of food engineering, v.32, p.133-154, 1997.

54. Helgerud, t.; gaserød, o.; fjæreide, t.; andersen, p.o.; larsen, c.k. Alginates. In: imeson, a. Food stabilisers, thickeners and gelling agents, p.50-72, 2009.

55. Hemati, a.; cherif, r.; saleh, k.;pont, v. Fluidized bed coating and granulation: influence of processo-related variables and physicochemical properties on the growth kinetics. Powder technology, v. 130, n. 1-3, p. 18-34, 2003.

56. Herculano, e. D. Óleo essencial de eucalyptus staigeriana nanoencapsulado para utilização como conservante em alimentos. 2014. 86f. Dissertação (mestrado em ciência e tecnologia de alimentos) - Universidade Federal do Ceará, Fortaleza, 2014.

57. Herrero, m.; cifuentes, a.; ibanez, e. Sub-and supercritical fluid extraction of functional ingredients from different natural sources: plants, food-by-products, algae and microalgae. A review. Food chemistry, v. 98, p. 136-148, 2006.

58. Holkem, a.t.; codevilla, c. F.; menezes, c. R. Emulsificação/gelificação iônica interna: alternativa para microencapsulação de compostos bioativos. Ciência e natura, v.37, ed. Especial-nano e microencapsulação de compostos bioativos e probióticos em alimentos, p. 116-124, 2015.

59. Jackson, l.s.; lee, k. Microencapsulation and food industry, lebensmittel-wissenschafat technologie, v. 24, n.4, p. 289-297, 1991.

60. Jain, n.k. Controlled and novel drugd delivery. Delhi cbs, 406p, 2004.

61. Jamekhorshid, a.; sadrameli, s. M.; farid, m. A review of microencapsulation methods of phase change materials (pcms) as a thermal energy storage (tes) médium. Renewable and sustainable energy reviews, v. 31, p. 531-542, 2014.

62. Juveriya, f., fathima, i.; abhishek, v.; khanum, f. Phosphatidylcholine, an edible carrier for nanoencapsulation of unstable thiamine. Food chemistry, v.197, p.562-570, 2016.

63. Kailasapathy, k.; masondole, 1. Survival of free and microencapsulated lactobacillus acidophilus and bifidobacterium lactis and their effect on texture of feta cheese. Aust $j$ dairy technol, v.60, n.3, p.252-258, 2005.

64. Kent, r. M.; doherty, s. B. Probiotic bacteria in infant formula and follow-up formula: microencapsulation using milk and pea proteins to improve microbiological quality. Food research international, v. 64, p. 567-576, 2014.

65. Krasaekoopt, w.; bhandari, b.; deeth, h. Review: evaluation of encapsulation techniques of probiotics for yoghurt. International dairy journal, v. 13, p. 3-13, 2003.

66. Koroshi, e. T. Estudo do processo de liofilização: aplicação para suco de laranja. 2005. 156p. Dissertação (mestrado em engenharia química). Faculdade de Engenharia Química, Universidade Estadual de Campinas, Campinas, 2005.

67. Kuck, 1.s. Microencapsulamento de compostos bioativos da uva (vitis labrusca 1.) E efeito do tratamento póscolheita com uv-c em uvas bordô. 2016. 106f. Tese (doutorado em ciência e tecnologia de alimentos) Universidade Federal do Rio Grande do Sul, Porto Alegre, 2016. 
68. Laine, p.; toppinen, e.; kivelä, r.; taavitsainen, v.; knuutila, o.; sontag-strohm, t.; jouppila, k.; loponen, j. Emulsion preparation with modified oat bran: optimization of the emulsification process for microencapsulation purposes. Journal of food engineering, v. 104, n. 4, p. 538-547, 2011.

69. Lam, p.l., gambari, r. Advanced progress of microencapsulation technologies: in vivo and in vitro models for studying oral and transdermal drug deliveries, journal of controlled release, v. 178, p. 25-45, 2014.

70. Laurenti, e.; garcia, s. Eficiência de materiais encapsulantes naturais e comerciais na liberação controlada de probiótico encapsulado/efficiency of natural and commercial encapsulating materials in controlled release of encapsulated probiotics. Brazilian journal of food technology, v. 16, n. 2, p. 107, 2013.

71. Lee, g. H.; shin, m. G. Production of spherical granule from viscous red ginseng extracts for improving product fluency and preservation and its physicochemical properties. Journal of food science, v. 74, n. 9, p. 519-525, 2009.

72. Lemos, y. P. Microencapsulação de óleo de buriti por coacervação complexa em matrizes de gelatina/alginato. 2017. 77p. Dissertação (mestrado em engenharia e ciência de alimentos) - Universidade Estadual Paulista, São José do Rio Preto, 2017.

73. Lévic, s.; lijaković, i.p.; đorđević, v.; rac, v.; rakić, v.; knudsen, t.s.; pavlović, v.; bugarski, b.; nedović, v. Characterization of sodium alginate/d-limonene emulsions and respective calcium alginate/d-limonene beads produced by electrostatic extrusion. Food hydrocolloids, v. 45, p. 111-123, 2015.

74. Liolios, c.c.; gortzi, o.; lalas, s.; tsaknis, j.; chinou, i. Liposomal incorporation of carvacrol and thymol isolated from the essential oil of origanum dictamnus L. And in vitro antimicrobial activity. Food chemistry, v.112, p.77-83, 2009.

75. Lupo, b.; maestro, a. Porras, m.; gutíerrez, j.m.; gonzález, c. Preparation of alginate microspheres by emulsification/internal gelation to encapsulate cocoa polyphenols, food hydrocolloids, 38, 56-65, 2014.

76. Lyng, s. M.; passos, m.; fontana, j. D. Bixin and $\alpha$-cyclodextrin inclusion complex and stability tests. Process biochemistry, v. 40, n. 2, p. 865-872, 2005.

77. Lyra, m.a.m.; alves, 1.d.s.; fontes, d.a.f.; soaressobrinho, j.1.; rolim-neto, p.j. Ferramentas analíticas aplicadas à caracterização de complexos de inclusão fármacociclodextrina. Revista de ciências farmacêuticas básica e aplicada, v.31, n.2, p.117-124, 2010.

78. Maia, j. L. Desenvolvimento de microcápsulas contendo as antocianinas presentes no corante do extrato do jambo por polimerização interfacial. 2013. 83f. Dissertação (mestrado em engenharia química) - Universidade Federal do Rio Grande do Norte, Natal, 2013.

79. Marques, 1.g. Liofilização de frutas tropicais. 2008. 293f. Tese (doutorado em engenharia química) Universidade Federal de São Carlos. São Carlos, 2008.

80. Marsanasco, m.; márquez, a.; wagner, j.; chiaramoni, n. Liposomes as vehicles for vitamins e and c: an alternative to fortify orange juice and offer vitamin $\mathrm{c}$ protection after heat treatment. Food research international, v.44, p. 3039-3046, 2011.

81. Martin del valle, e.m. Cyclodextrins and their uses: a review. Process biochem., v.39, n.9, p.1033- $1046,2004$.

82. Martín, j. M.; lara-villoslada, f.; ruiz, m.a.; morales, m.e. Microencapsulation of bacteria : a review of different technologies and their impact on the probiotic effects. Innovative food science and emerging technologies, v. 27, p. 15-25, 2015.

83. Matalanis, a.; jones, o.; mcclements, d. J. Structured biopolymer-based delivery systems for encapsulation, protection, and release of lipophilic compounds. Food hydrocolloids, v. 25, n. 8, p. 1865-1880, 2011.

84. Matioli, g.; rodriguez-amaya, d. B.; microencapsulação do licopeno com ciclodextrina. Ciência e tecnologia de alimentos, v.23, supl., p.102-105, 2003.

85. Mcclements, d. J. Theoretical analysis of factors affecting the formation and stability of multilayered colloidal dispersions. Langmuir, v. 21, n. 21, p. 9777-9785, 2005.

86. Mendanha, d. V.; ortiz, s.e.m.; favaro-trindade, c.s.; mauri, a.; monterrey-quintero, e.s.; thomazini, m. Microencapsulation of casein hydrolysate by complex coacervation with spi/ pectin. Food res. Intern. V. 42 , p. 1099-1104, 2009.

87. Menezes, c. R.; barins, j.s.; chicoski, a.j.; zepka, 1.q.; jacob-lopes, e.; fries, 1.1.m.; terra, n.n. Microencapsulação de probióticos: avanços e perspectivas. Ciência rural, v. 43, n. 7, p. 1309-1316, 2013.

88. Mortazavian, a. M.; sohrabvandi, s. Probiotics and food probiotic products; based on dairy probiotic products. Tehran: eta publication, p. 54-155, 2006.

89. Murthy, z. V. P.; joshi, d. Fluidized bed drying of aonla (emblica officinalis). Drying technology, v. 25, n. 4-6, p. 883-889, 2007.

90. Mukai-corrêa, r.; prata, a.s.; alvim, i.d., grosso, c.r.f. Controlled release of protein from hydrocolloid gel microbeads before and after drying, current drug delivery, v. 1, n. 3, p. 265-273, 2004. 
91. Müller, j. M.; santos, r. L.; brigido, r. V. Produção de alginato por microrganismos. Polímeros, v. 21, n. 4, p.305-310, 2011.

92. Murthy, z. V. P.; joshi, d. Fluidized bed drying of aonla (emblica officinalis). Drying technology, v. 25, n. 4-6, p. 883-889, 2007.

93. Nedovic, v.; kalusevic, a.; manojlovic, v.; levic, s.; bugarski, b. An overview of encapsulation technologies for food applications. Procedia food science, v. 1, p. 1806-1815, 2011.

94. Nesterenko, a.; alric, i.; silvestre, f.; durrieu, v. Vegetable proteins in microencapsulation: a review of recent interventions and their effectiveness. Industrial crops and products, v. 42, p. 469-479, 2013.

95. O'donnell, p. B.; mcginity, j. W. Preparation of microspheres by the solvent evaporation technique. Advanced drug delivery reviews, v.28, n.1, p.25-42, 1997.

96. Oliveira junior, g. R.; oliveira, g.r.; santos, j.t.s.; campos, a.f.p.; nunes, t.p.; russo, s.l. Prospecção tecnológica: processo de liofilização na indústria de alimentos. Revista geintec, v. 3, n. 1, p.92-102, 2012.

97. Orrego, a. C. E. Congelación y liofilización de alimentos. Gobernación de caldas, 172p, 2008. Disponível em <http://www.bdigital.unal.edu.co/7837/1/9789584444363.pdf>. Acesso em 25 de novembro de 2018.

98. Paglione, i. S. Produção e caracterização de filmes biodegradáveis de isolado proteico de soja contendo micropartículas de óleo essencial de orégano. 2018. 62f. Dissertação (mestrado profissionalizante em tecnologia de alimentos) - Universidade Tecnológica Federal do Paraná, Londrina, 2018.

99. Pandit, v.; gorantla, r., devi, k., pai, r.s.; sarasija, s. Preparation and characterization of pioglitazone cyclodextrin inclusion complexes. Journal of young pharmacists, v.3, p. 267-274, 2011.

100.Parikh, d. M. Airflow in batch fluid-bed processing. Pharmaceutical technology, n. 15, v. 3, p. 100-110, 1991.

101.Park, d.; maga, j. A. Identificação de voláteis chave responsáveis pelas diferenças de qualidade de odor na pipoca estourada de híbridos selecionados. Food chemistry, v. 99, n. 3, p. 538-545, 2006.

102.Patil, j. S.; kamalapur, m. V.; marapur, s. C.; kadam, d. V. Ionotropic gelation and polyelectrolyte complexation: the novel techniques to design hydrogel particulate sustained, modulated drug delivery system: a review. Digest journal of nanomaterials and biostructures, v. 5, n. 1, p. 241-248, 2010.

103.Paulo, b. B. Estratégias para produção de partículas lipídicas em leito fluidizado. 2017. 170f. Dissertação (mestrado em engenharia dos alimentos) - Universidade Estadual de Campinas, Faculdade de Engenharia de Alimentos, Campinas, 2017.

104.Pereda, j.a.o. Tecnologia de alimentos. Porto Alegre - rs: artmed, 2005.

105.Pereira, k.c.; ferreira, d.c.m.; alvarenga, g.f.; pereira, m.s.s.; barcelos, m.c.s.; da costa, j.m.g. Microencapsulação e liberação controlada por difusão de ingredientes alimentícios produzidos através da secagem por atomização: revisão. Braz. J food technol, v. 21, 2018.

106.Pereira, t. Microencapsulação do óleo eugenol pelo método de spray dryng. 2007. 47f. Trabalho de conclusão de curso (bacharel em química) - Universidade Federal de Santa Catarina, Florianópolis, 2007.

107.Poncelet, d., babak, v., dulieu, c., picot, a. A physico-chemical approach to production of alginate beads by emulsification-internal ionotropic gelation, colloids and surfaces a: physicochemical and engineering aspects, $\mathrm{v}$. 155, n. 2-3, p. 171-176, 1999.

108.Poncelet, d. Production of alginate beads by emulsification/internal gelation. Ann n y acad sci, v. 944, p.74-82, 2001.

109.Pothakamury, u.r.; barbosa-cánovas, g.v.fundamental aspects of controlled release in foods. Trends food sci. Technol, v.6, p.397-406, 1995.

110.Phisut, n. Spray drying technique of fruit juice powder: some factors influencing the properties of product. International foodresearch journal, v. 19, p. 1297-1306, 2012.

111.Rebello, f. F. P. Microencapsulação de ingredientes alimentícios. Revista agrogeoambiental, v. 1, n. 3, p. 134144, 2009.

112.Rocha, 1.c.r. Desenvolvimento de micropartículas contendo suco de tomate via gelificação iônica. $2017.87 \mathrm{f}$. Dissertação (mestrado em engenharia de biomateriais) - Universidade Federal de Lavras, Minas Gerais, 2017.

113.Rodríguez, j.; martín, m. J.; ruiz, m. A.; clares, b. Current encapsulation strategies for bioactive oils: from alimentary to pharmaceutical perspectives. Food research international, v. 83, p. 41-59, 2016.

114.Rosenberg, m.; young, s.1. Whey proteins as microencapsulating agents. Microencapsulation of anhydrous milkfat-struture evaluation. Food structure. Chicago, v. 12, n. 1, p. 31-41, 1993.

115.Rosen, r. M. Manual do sistema de entrega para cuidados pessoais e produtos cosméticos. Tecnologia, aplicações e formulações. Nova York: william andrew, 2006. 
116.Sakata, s.; uchida, k.; kaetsu, i.; kita, y. Programming control of intelligent drug releases in response to single and binary environmental stimulation signal using sensor and electroresponsive hidrogel. Radiation physics and chemistry, v.76, p.733-737, 2007.

117.Saleh, k.; guigon, p. Coating and encapsulation process in powder techonology. In: salman, a. D.; hounslow, m.j.; seville, j.p.k. Granulation, p.324-375, 2007.

118.Santos, a. B.; favaro-trindade, c.s.; grosso, c.r.f. Preparo e caracterização de microcápsulas de oleoresina de páprica obtidas por atomização. Ciênc. Tecnol. Alimentos, v. 25, n. 2, p. 322-326, 2005.

119.Santos, m. G.;bozza, f. T.; thomazini, m.; favaro-trindade, c. S. Microencapsulation of xylitol by double emulsion followed by complex coacervation. Food chemistry, v. 171, p. 32-39, 2015.

120.Sarkar, s.; gupta, s.; variyar, p. S.; sharma, a.; singhal, r. S. Irradiation depolymerized guar gum as partial replacement of gum arabic for microencapsulation of mint oil, carbohydrate polymers, v. 90, n. 4, p. 16851694, 2012.

121. Schoubben, a.; blasi, p.; giovagnoli, s.; rossi, c.; ricci, m. Development of a scalable procedure for fine calcium alginate particle preparation. Chemical engineering journal, v.160, n.1, p.363-369, 2010.

122.Silva, c. M.;ribeiro, a. J.; figueiredo, i. V.; gonçalves, a. R.; veiga, f. Alginate microspheres prepared by internal gelation: development and effect on insulin stability. International journal of pharmaceutics, v. 311, n. 1-2, p. 110, 2006.

123. Silva, k.c.g. Produção de microgéis simbióticos de gelatina-alginato e simulação da liberação controlada em condições gastrointestinais. 2016. 110f. Dissertação (mestrado em engenharia de alimentos) - Universidade Estadual de Campinas, Campinas, 2016.

124.Silva, p. T.; fries, 1. L. M.; menezes, c. R.; holkem, a. T.; schwan, c. L.; wigmann, e. F.; bastos, j. O.; silva, c. B. Microencapsulation: concepts, mechanisms, methods and some applications in food technology. Ciência rural, v. 44, n. 7, p. 1304-1311, 2014.

125.Silva, t. M.; rodrigues, 1. Z.; nunes, g. L.; codevilla, c. F.; silva, c. D. B.; menezes, c. R. Encapsulation of bioactive compounds by complex coacervation. Ciência e natura, v. 37, p. 56 - 64, 2015.

126.Smrdel, p.; bogataj, m.; zega, a.; planinšek, o.; mrhar, a. Shape optimization and characterization of polysaccharide beads prepared by ionotropic gelation. Journal of microencapsulation, v. 25, n. 2, p. 90-105, 2008.

127. Sobrinho, e. C. S.; farias, m. C. A microencapsulação na indústria alimentícia. Infarna, v. 24, p. 84-93, 2012.

128. Sohail, a.; turner, n.s.; coombes, a.; bostrom, t.; bhandari, b. Survivability of probiotics encapsulated in alginate gel microbeads using a novel impinging aerosols method. International journal of food microbiology, v.145, p. 162-168, 2011.

129. Snowman, j. W. Freeze dryers. In: baker, c. G. J. Industrial drying of foods, p.134-145, 1997.

130.Souza, v. B. Extração e encapsulação por coacervação complexa das proantocianidinas da canela (cinnamomum zeylanicum blume). 2016. 185f. Tese (doutorado em ciências) - Faculdade de Zootecnia e Engenharia de Alimentos da Universidade de São Paulo, Pirassununga, 2016.

131.Stojanovic, h.; belscak-cvitanovic, a.; manojlovic, v.; komes, d.; nedovic, v.; bugarski, b. Encapsulation of thyme (thymus serpyllum 1.) Aqueous extract in calcium alginate beads. Jounal of the science of food and agriculture, v. 92, n.3, p. 685-696, 2012.

132.Suave, j.; dallagnol, e. C.; pezzin, a. P. T.; silva, d. A. K.; meier, m. M.; soldi, v. Microencapsulação: inovação em diferentes áreas. Revista saúde e ambiente, v.7, n.2, p.12-20, 2006.

133. Szejtli, j. Introduction and general overview of cyclodextrin chemistry.chem. Rev, v.98, n.5, p.1743-1754,1998.

134. Szente, 1.; szejtli, j. Molecular encapsulation of natural and synthetic coffee flavor with -cyclodextrin. J. Food sci., v.51, p.1024-1027, 1986.

135.Teixeira, v. F. T.; pereira, n. R.; waldman, w. R.; ávila, a. L. C. D.; pérez, v. H.; rodríguez, r. J. S. Ion exchange kinetics of magnetic alginate ferrogel beads produced by external gelation, carbohydrate polymers, v.111, p.198-205, 2014.

136. Tewes, f.; boury, f.; benoit, j. Biodegradable microspheres: advances in production technology. In: benita, s.; francis, t. Microencapsulation: methods and industrial application, v.2, 2006.

137.Toldrá, f.; reig, m. Inovações para carnes processadas mais saudáveis. Tendências em ciência e tecnologia de alimentos, v. 22, n. 9, p. 517-522, 2011.

138.Torres, j.a.; karel, m. Microbial stabilization of intermediate food surfaces. Iii. Effects of surface preservative concentration and surface ph control on microbial stability of an intermediate moisture cheese analog. J. Food process. Pres, v.9, n.2, p.107-119, 1985.

139.Venkatesan, p.; manavalan, r.; valliappan, k. Microencapsulation: a vital technique in novel drug delivery system. J. Pharm. Sci. Res, v.1, n.4, p.26-35, 2009. 
140.Vos, p., faas, m. M., spasojevic, m., sikkema, j. Encapsulation for preservation of functionality and targeted delivery of bioactive food components, international dairy journal, v. 20, n. 4, p. 292-302, 2010.

141.Wang, w.; waterhouse, g. I.; sun-waterhouse, d. Co-extrusion encapsulation of canola oil with alginate: effect of quercetin addition to oil core and pectin addition to alginate shell on oil stability. Food research international, v. 54, n.1, p. 837-851, 2013.

142. Wechtersbach, 1.; poklarulrih, n.; cigic, b. Liposomal stabilization of ascorbic acid in model systems and in food matrices. Food science and technology, v.45, p.43-49, 2012.

143. Weiss, j.; takhistov, p.; mcclements, j. Functional materials in food nanotechnology. Journal of food science, v. 71, p. 107-116, n. 9, 2006.

144.Wong, s. W.; yu, b.; curran, p.; zhou, w. Characterising the release of flavour compounds from chewing gum through hs-spme analysis and mathematical modelling. Food chemistry, v. 114, n. 3, p. 852-858, 2009.

145.Yang, x.; gao, n.; hu, l.; li, j.; sun, y. Development and evaluation of novel microcapsules containing poppyseed oil using complex coacervation. Journal of food engineering, v. 161, p. 87-93, 2015.

146.Fukumori, y.; ichikawa, h. Fluid bed processes for forming functional particles. Encyclopedia of pharmaceutical technology, v.3, p. 1773-1778, 2007. Disponível em: 〈http://www.gmpua.com/process/encyclopediapt.pdf〉. Acesso em 27 de novembro de 2018.

147.Zandi, m.; dardmeh, n.; pirsa, s.; almasi, h. Identification of cardamom encapsulated alginate-whey protein concentrates microcapsule release kinetics and mechanism during storage, stew process and oral consumption. Journal of food processing enginnering, v. 40, p. 1-11, 2015.

148.Zhang, h.; tumarkin, e.; sullan, r. M. A.; walker, g. C.; kumacheva, e. Exploring microfluidic routes to microgels of biological polymers. Macromolecular rapid communications, v. 28, n. 5, p. 527-538, 2007. 